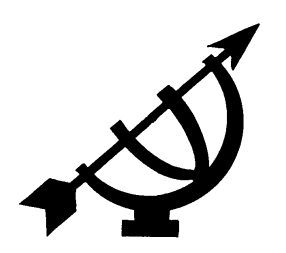

\title{
Should humans interfere in the lives of elephants?
}

\author{
H.P.P. (Hennie) Lötter \\ Department of Philosophy \\ University of Johannesburg \\ AUCKLANDPARK \\ E-mail: hppl@lw.rau.ac.za
}

\begin{abstract}
Should humans interfere in the lives of elephants?

Culling seems to be a cruel method of human interference in the lives of elephants. Culling is generally used to control population numbers of highly developed mammals to protect vegetation and habitat for other species. Many people are against human interference in the lives of elephants. In this article aspects of this highly controversial issue are explored. Three fascinating characteristics of this ethical dilemma are discussed in the introductory part, and then the major arguments raised against human interference in the lives of elephants are evaluated. These arguments are the following: First, that nature should be allowed to run its course and establish its own balance; nature will thus solve the problem of elephant over-population. The second argument raised by animal-rights activists as well as by animal-welfare groups either claim that animals have rights that humans must respect at all times, or that all sentient beings have interests that humans ought to respect, as those beings can experience pleasure or pain. The third argument often associates culling elephants as method for population control with the commercial use and exploitation of wilderness areas. Many people argue that it is unethical to use wildlife as a sustainable resource for fighting poverty. In conclusion it is stated that despite these arguments human intervention in the lives of elephants is ethically justified.
\end{abstract}

\section{Opsomming}

\section{Behoort die mens in te meng in die lewens van olifante?}

Die uitdunning van olifante lyk na 'n wrede manier waarop die mens inmeng in die lewens van olifante. Die metode van 
uitdunning word gebruik om die bevolkingsgetalle van hoogs ontwikkelde soogdiere te beheer om sodoende die plantegroei en habitat vir ander spesies te bewaar. Baie mense is daarteen gekant dat die mens inmeng in olifante se lewens. Aspekte van hierdie hoogs omstrede kwessie word in hierdie artikel ondersoek. Drie fassinerende kenmerke van hierdie etiese dilemma word bespreek en daarna word die belangrikste argumente teen menslike inmenging in die bestaan van olifante geëvalueer. Hierdie drie argumente is die volgende: Eerstens, dat die natuur sy eie gang moet gaan om daardeur self 'n balans te bewerkstellig; die natuur sal dus self die oorbevolking van olifante regstel. Die tweede argument wat deur diereregteen dierewelsynsgroepe aangevoer word, eis óf dat diere regte het wat te alle tye deur mense gerespekteer moet word, óf dat diere met waarnemingsvermoë belange het wat mense moet respekteer, omdat hierdie lewende wesens genot en pyn kan ervaar. Die derde argument assosieer die uitdunning van olifantgetalle as 'n metode van getallebeheer met die kommersiële benutting en uitbuiting van wildernisgebiede. Baie mense is oortuig dit is oneties om wilde diere as volhoubare bron te benut om armoede mee te beveg. Die slotsom waartoe gekom word is dat ten spyte van hierdie argumente menslike inmenging in die lewens van olifante tog eties geregverdig is.

\section{Introduction ${ }^{1}$}

To substantiate different aspects of the argument about the issue of managing elephant numbers and the pros and cons of human intervention in the lives of elephants, several relevant situations, ${ }^{2}$ structured and formulated as narrated stories will be incorporated into the line of argumentation. These stories are imaginative

1 Earlier versions of this article were presented at different places: (i) the annual conference of the Southern African Philosophical Association (Pietermaritzburg in January 2004), (ii) The Great Elephant Indaba organised by the Wildlife and Environmental Society of South Africa (Nelspruit in August 2004), (iii) a teleconference organised by the Transboundary Protected Areas Research Initiative (March 2004) and (iv) the Departments of Philosophy (February 2004) and Zoology (April 2004) at the University of Johannesburg. I would like to thank the following people for their discussions and debates with me on elephant issues, as well as for enabling me to observe elephant behaviour, impacts, and habitats: Michelle Henley, Steve Henley, lan Whyte, Audrey Delsink, Douw Grobler, David Mabunda, Josias Chabani, Howard Blight, Norman Owen-Smith, Johan du Toit, Lucas Rutina, Frederick M. Dipotso, and Elizabeth Masuku. Marc Basson improved my use of the English language.

2 Specific narratives substantiating the main argument will be formatted in italics and presented without quotation marks. 
fictionalisations that are loosely based on facts, though predominantly reflecting my (HPPL's) interpretations of such facts. Certain excerpts from already published observations of other people are also enclosed as quotations substantiating a specific aspect of the argument. This method of including narratives is also applied to depict real-world situations and thus lending the problem and issue to be investigated directness of appeal. Summing up: These narrations emphasise that decisions about the management of elephants affect many areas: the lives of human beings, other animal species, ecological and biodiversity systems as well as the opinions of concerned supporters of conservation areas.

At the outset of the article the diverse problems and frustrations experienced by of three people from different walks of life, and living in different parts of the world are depicted. Each of these people are directly or indirectly involved in the concomitant problems of an elephant population that has grown out of proportion: An official also acting as wildlife manager in the Kruger National Park ponders how the issue about elephants numbers should be addressed. A Botswana inhabitant whose crops are ruined by elephants wonders how he and his family will survive without income. An overseas activist who wants to conserve wild life at all costs takes the war path. In this respect these narratives relating to the position of elephants are rooted in everyday life situations and thus efficiently illustrate the variety of problems to be discussed in this article.

In Skukuza, the administrative headquarters of the magnificent 19000 square kilometer Kruger National Park (KNP) in north eastern South Africa, lan Whyte sits in his office, pondering the information about the park's elephant population. The KNP's successful conservation strategies have re-established elephants in this vast area where they were hunted almost to extinction in the 19th century. From only a few tracks in the sand in 1903 the population has grown to 11671 in 2003, unfortunately much more than the park's scientists believe its vegetation can support. The destructive feeding habits of these wonderful animals that lan loves so much can change the woodland vegetation of the park into grassland, thus endangering the continued existence of many plant, bird, reptile, insect, amphibian, and mammal species. Ian thus ponders how he should advise the KNP management. Should the KNP start a culling programme again, as they did efficiently to keep elephant numbers in check from 
1967 to 1994? Does a loss of other species and major change in landscape warrant destroying family herds? Are these good enough reasons to kill specimens of the world's largest mammal instantaneously by means of a gunshot in the brain, fired by a game warden from a helicopter? Would the elephants being killed communicate their fear and distress by using their infrasound communication - sounds that we humans cannot hear - to alert other herds up to ten kilometers away? Will local and international individuals and NGO activists once again respond by court interdicts and boycotts to pressurise the KNP to stop their culling programme, as they did in 1995?

In Mahawe in northern Botswana, Sipho Morake is furious. Last night the elephants raided his crops again. He and his sons tried to chase them away with fires and the sound of drums, but the elephants have become used to these scare tactics. Instead of running away, they charged and almost killed one of his sons. Fortunately no one was hurt, so at least they were not as unlucky as their neighbour, whose nephew was killed by an elephant two weeks ago. Sipho does not know how his family will survive the next winter. Almost half his crops has been destroyed thus far this year and the government does not pay any compensation for losses caused by elephants. He will have to find a better way to deal with these problem elephants. Perhaps he could try digging deep holes for the elephants to fall into and then kill them - this method his grandfather said worked quite well for their ancestors. Maybe he should try to get a rich hunter who could even pay him to shoot the problem animals. This option, however, could be risky, as the government has banned the hunting of animals several years ago. If only he could get rid of these damn elephants that disrupt his life, impoverish his already poor family, and even kill members of his community! He cannot understand why the government does not exterminate them and give the land to his people for farming purposes.

In London, Jason Smith is on his way to a very important meeting of his favourite organisation, Born Free. Tonight they are going to plan a strategy to force the national parks in South Africa, Zimbabwe, and Botswana not to even consider culling programmes in the near future. He is excited and angry. His excitement was sparked by the 
recent successes in the conservation of elephants after the disastrous crash in their numbers caused by the cruel and wasteful poaching slaughter of elephants for their ivory in the 1980s. 3 After CITES had banned trade in ivory in 1989, the killings have sharply diminished. Elephants have found respite from human persecution and extirpation in many parts of Africa and Asia. There is no way that Jason and his fellow activists will allow these gains to be undone by the ruthless killing of elephants by the very people supposed to be custodians of African wildlife! The idea of game rangers shooting defenseless elephants from the safety of a helicopter ignites his anger. The procedure of wiping out an entire herd, starting with the matriarch and then the older cows so as to disorient the others, and thus preventing their escape, is cruel and unbefitting of such awe-inspiring creatures. No, Jason says to himself, we will not allow this. We will teach these Third World conservationists in the south to respect the rights of every individual animal in their care - even if it requires us to organise an international tourist boycott of those conservation areas and to advocate a ban of all their exports to First World countries. Such a campaign would be exciting. At tonight's meeting Leonardo DiCaprio, the film idol, will be present to discuss his role to launch the campaign and draw in funds. Let the struggle continue!

Elephants have excited human interest and elicited human fascination ever since the first contact between the two species thousands of years ago. Elephants' mammoth size as the largest land animal, their intelligence and renowned memory, and their gentle social nature have drawn appreciation and wonder from humans in different cultures throughout history. Nonetheless, their economic value as trainable servants in Asia and bearers of ivory in Africa has almost led to their extinction in the 20th century. As one of the world's charismatic mega-fauna, elephants attract human attention and their fate concerns lots of people everywhere (see Ginsberg, 2002:1190).

For these reasons, the management of elephants anywhere on the planet is an international issue. The methods which conservationists suggest and wildlife managers implement to deal with local issues of 
habitat destruction supposedly caused by elephants, and the resultant loss of species in conservation areas, are scrutinised and carefully evaluated by interested parties all over the world. How governments deal with wildlife that causes crop losses and loss of life in rural Africa is monitored and judged by concerned environmentalists around the globe. And rightly so. These issues might not affect the survival of living beings on earth to the same extent as pollution, deforestation, and global warming. However, the conservation of the diversity of life forms to prevent their extinction at human hands is surely a legitimate way of preserving a heritage humans have been bequeathed by millions of years of evolution, growth, and development of life on earth.

Culling excess animals in conservation areas is a highly controversial and emotional issue wherever it occurs (Hanks, 1979:43; Whyte, 2002:293). Somehow killing animals seems heavily at odds with the conservation bodies' mandate to protect animal and plant species. Conservationists must protect them because we humans have endangered non-human living beings through our continuously expanding presence in almost all areas on earth and our domination and exploitation of natural resources.

Culling seems to be a cruel method of human interference in the lives of elephants. It aims to control population numbers of highly developed mammals just to protect vegetation and habitat for other less important species - culling seems to be a method that ought not to be allowed (Sukumar, 2003:224). More importantly, many people are against any human interference in the lives of elephants. Is the issue, however, that simple? In this article I want to explore aspects of this highly controversial and emotive issue, the so-called "elephant problem". I will first discuss three fascinating characteristics of this ethical dilemma and then discuss the major arguments raised against human interference in the lives of elephants. This discussion leads to a conclusion that strong arguments can be made to justify human intervention in ecological processes in conservation areas.

The ethical issue of whether humans should interfere with elephant numbers raises a host of different questions. This ethical dilemma has three particular characteristics that make it a fascinating challenge to resolve. These characteristics are the following: the complex and intertwining set of issues engendered by this matter; the urgency of making a decision concerning a matter that has consequences that become more complicated whilst making up 
one's mind; and the complex role of science and emotions in the process of decision making.

\subsection{Interfering with elephants: a complex set of intersecting issues}

To make a responsible decision about human interference with elephant numbers, one has to be open to the diversity of questions generated by this issue. Being open leads to the discovery of a set of complex intersecting issues such as the following:

- The conservation of individual animals intersects with the conservation of species, habitat, ecosystems, and biodiversity.

- The safety and security of humans and the integrity of their property intersects with the protection of free-roaming animals.

- Human poverty in environments not suited for farming intersects with the utilisation of those environments' rich natural plant and animal (wildlife) resources. Such utilisation has the potential of improving the life of thousands of people in ways consistent with their cultural traditions that have been developed and nurtured over hundreds of years.

Further questions raised by the control of elephant numbers include the following: What are the relations humans ought to have with other animals? What are the goals of nature conservation? How do we judge human overpopulation and our destruction of the environment that strongly affects other living beings? To what extent can humans accommodate the interests of animals when these interests are in conflict with ours? Does sustainable use of natural resources include elephants or are they exempt from human utilisation? Should the victims of past injustices committed during the establishment of conservation areas be compensated, and what are the functions and responsibilities of the state in protecting the lives and bodies of citizens and safeguarding their property?

Taking the intertwining nature of the complex of issues generated by the control of elephant numbers seriously, emphasises the need for a holistic perspective to avoid a restricted vision of one issue only.

\subsection{Making a decision or not - there are consequences}

A second fascinating characteristic makes the ethical issue of human interference in the lives of elephants an urgent one. This issue cannot be avoided, as the problem has increased over time. A 
case study will illustrate the point. Since the Kruger National Park in north eastern South Africa placed a moratorium on culling in 1995 to review their elephant-management policy (Whyte, 2001:2; Whyte et al.,1999:111), the number of elephants has increased from the previously desired number of between 6000 and 8000 elephants to 11671 in 2003. Whilst reviewing their policy since 1995, elephants have still been increasing by an estimated growth rate of $7 \%$ annually and they continue feeding in their robust way; thus modifying their habitat. Reports of excessive modification, which amounted to destruction, were made by a senior manager, and if culling were to be resumed, large numbers of elephants might have to be culled if judged according to the pre-1995 policy requirements (Whyte, 2002:305).

Refusing to take a decision on the issue of limiting elephant numbers thus in fact implies to take sides; it implies a choice to let nature be, a preference to let matters develop without any human intervention. In this case, and by doing nothing, wildlife managers are actually making a choice for which they ought to be held accountable to the same extent as for any other conscious, deliberate choice. Their choice to do nothing is actually a major intervention in the short-term interests of all individual elephants. This choice, according to some ecologists, violates the interests of other animal species, vegetation, and landscapes in the long run. There seems to be, then, no neutral ground in conservation areas.

Whatever choice wildlife managers make in managing elephant populations, choices regarding this issue have consequences that cannot be ignored in any way, as they are there for everyone to see. For this reason a consequentialist ethical approach cannot be dismissed. Increased or decreased numbers of elephants, largescale destruction of woodlands to turn them into grasslands, or limited signs of elephants' robust feeding habits - decisions about the management of elephants affect the lives of thousands of animals, plants, all other living species, human visitors, and concerned supporters of conservation areas (see Mosugelo et al., 2002:235, 237, 238; Mapaure \& Campbell, 2002:216). To allow elephants to increase without intervention has consequences for the everyday duties of park rangers who witness and monitor the changes - changes that eventually lead to the disappearance of habitats and species. It is a definite long-term possibility to observe a devastating population crash, as in Tsavo East during the drought of 1970-1971, as a result of elephant overpopulation. Similarly, to choose culling is to expose some people to killing scenes of 
magnificent animals, as well as to involve others in removing carcasses and processing meat, hides, and ivory in professionally managed abattoirs. Unfortunately, at least some wildlife managers will then have to deal with the grim logistics of large-scale culling operations. In this ethical debate, consequences of decisions play a huge role.

\subsection{Science versus emotion}

When debating the issue of limiting the numbers of the elephant population the following slogan is often emphasised: Science has information, not answers. Emotions have attitudes, not solutions.

The role of science and emotions provides a third gripping characteristic of the controversial ethical issue of managing elephants. Science and emotions seemingly stand diametrically opposed regarding the issue of limiting elephant numbers, especially as regards the practice of culling elephants. The cool, calculating gaze of the scientist is supposedly the one to rationally resolve this issue, as scientists have access to the hard facts that alone can and ought to guide policy recommendations (Gillson \& Lindsay, 2003:411-419). At least, so some scientists believe; these scientists try, in typical positivist fashion, to detach their emotions from their decision making. The extent to which they fail is shown by the diversity of contrasting views scientists have on the issue of culling. Scientists familiar with elephant behaviour, conversant with the standard literature on elephants, and knowledgeable about the history of elephant management in conservation areas, nevertheless, disagree vehemently on whether culling is necessary for the health of conservation areas.

Is human interference not a matter of science: of specialised disciplines like ecology or wildlife management? So why judge that ethics can resolve this issue? Judging numerous scientific and popular scientific publications makes it clear that scientists look at the same data and information, yet interpret it differently, and in the process reach incompatible conclusions. Where do their differences come from? Some of them give priority to one species (elephants) above others, while others judge that ecosystems and biospheres have priority above individual animals. Some have a conception of nature that suggests it functions best when left alone without human interference, whilst others wish to aid nature in countering undue and undesirable human influences. Thus, scientists use more than scientific information when thinking about the acceptability of limiting elephant numbers: several value choices influence their stance (see 
Elliot, 1991:284). Science does not provide the answers for the problem of human interference, but merely the information that needs to be taken into account in decision making on such policies (Owen-Smith, 1988:xi).

So-called scientific thinkers believe emotions will only cloud and distort the issue, resulting in irrational ranting and raving that prevents the give and take of rational dialogue (see Irven Buss, 1990:175; Hanks, 1979:43). Reacting against this one-sided scientific approach based on our observations and calculating reason, many activists and concerned citizens are guided by their deeply felt emotions for elephants. They find it unimaginable to kill sociable, gentle, intelligent animals that resemble us in so many ways, for what are to them such unconvincing reasons. Rather than distorting and blurring the issue, they experience their emotions as guides to show the value elephants have for us. Emotions delineate the limits of what human beings may do to elephants. However, whilst emphasising the value of emotions in this controversial, difficult debate, some individuals and groups often base decisions one-sidedly on emotions, excluding reason. This narrow reliance on emotions leads people to be unwilling participants in dialogue, to reject other positions outright, to threaten their adversaries with reprisals, and to ignore any form of scientific evidence and reasoning.

And yet, to reject emotions in the debates on limiting elephant numbers, and especially on the practice of culling, would be shortsighted, as emotions are far more valuable than merely clouding issues or distorting facts. To look at the facts clinically by rejecting any undue influence of emotions is then clearly undesirable. Only callous people can say that killing (special) animals is unemotional; only insensitive observers can deny that experiencing nature's rich biodiversity is awesome or amazing; only inattentive tourists without empathy can observe elephants interacting as families and not be moved. Emotions alert us to significant issues, they make us aware of what is of value, and require us to rethink the significance of what we encounter and observe. Once we have reflected on such issues, the consequent emotions can be judged to be rational, as they signify the appropriate value we ought to attach to something, someone, an event, or action. The enormous emotional sensitivity about the accusation that their scientific management practices were unethical, stopped culling in the Kruger National Park in 1995. This event underlines how scientists and managers of the Kruger National Park took emotions seriously and responded to highly 
emotional accusations that must have resonated somewhere inside themselves. Wildlife scientists and managers passionate about conserving animals, experience emotions of sadness and regret when the animals they conserve or study have to be killed.

\section{Conclusion 1:}

It is our choice, based on our ethics (moral values), that we want to implement as goals for conservation areas and these goals eventually end up as guidelines for management practices; there is no scientific information or data that forces us to make a definite choice one way or the other (see Whyte, 2001:154; Owen-Smith, 1988:298; Leuthold, 1996:101-112). Emotions about conservation issues must be critically interrogated to become meaningful guides to action in conjunction with reason and ethics.

\section{Arguments against human interference in the lives of elephants}

\section{1 "Leave nature alone; do not interfere"}

One of the strongest arguments against human interference in the lives of elephants is based on the idea that nature should be allowed to run its course and establish a balance that changes over time. This idea rests on firm scientific evidence from many disciplines, especially ecology itself. For a long time ecologists supported the so-called equilibrium paradigm, which implies that nature itself establishes a delicate harmony and balance between various life forms that humans can easily upset. Thus, they concluded, humans should not interfere. Nowadays, however, the disequilibrium paradigm is in vogue, which depicts the constant flux in ecosystems that has occurred through natural processes over millions of years. Nature needs an intermediate level of ecological disturbance so as to produce the highest levels of heterogeneity of conditions and life forms. Constant flux in nature through a diversity of ecological processes must be respected as nature's way of allowing life on earth to flourish. Again, the conclusion is that humans should let nature take its course.

Both paradigms require minimum human intervention in natural processes at any level. The fact that humans do not fully understand all ecological processes at work, and have so often destroyed or disturbed such processes through harmful interference, reinforces the idea that nature is better off left to its own devices. Sometimes 
any kind of human intervention is regarded as harmful human control, whilst nature is spelt with a capital $\mathrm{N}$ and described as almost divine: benevolent ("Nature will do what is good"), omniscient ("Nature knows best"), and omnipotent ("Nature can and will sort out these difficult problems"). Humans can do no better than allowing nature to be free and to develop according to its own dictates.

The strong version of this argument implies that wildlife managers must let nature be and the elephant problem will sort itself out. This solution works as follows: Elephants have a robust feeding pattern that gradually changes woodland into grassland, destroys the habitat of some species and creates conditions for other species to flourish, and eventually a population of elephants may even crash under severe conditions, because they have depleted their own food resources (Owen-Smith, 1988:264). Maybe the population will not crash but merely move away to other areas where there is a better habitat. Or maybe depleted food resources will bring down elephants' rate of reproduction. Thus elephants will eventually relieve pressure on their existing home range as a result of the benevolent functioning of natural ecological processes that have developed over millions of years. Some scientists place their hopes on the advent of trans-frontier parks or the establishment of corridors between conservation areas to enhance the feasibility of this option, as larger areas become available within which ecological processes can operate.

Proponents of this view believe that drastic changes to the environment and its population of living beings caused by the impact of elephants are nothing to worry or get excited about. These changes are merely highly visible phenomena when viewed in shortterm perspective, but normal natural occurrences when observed as part of larger natural cycles spanning time scales of hundreds of years (see Buss, 1990:173). The scientific evidence for these benevolent natural cycles is mostly rather flimsy, as detailed bookkeeping of natural phenomena and events, let alone the scientific study of nature, does not go back more than a century or so (see Whyte, 2002:295). According to Gillson and Lindsay (2003: 417) "Most data-sets cover periods of decades, at best, whereas many ecological processes take much longer, particularly with animals and plants sharing long life-history parameters, such as elephants and trees." To rely on these ideas with short-term, inadequate supporting evidence about natural cycles is thus to trust speculative ideas which may, or may not, lead to damage to landscapes and ecosystems and harm several species of living 
beings (see Whyte, 2001:301-302; Osborn \& Parker, 2003:3). Such damage may take centuries to recover, if ever. The ethical issue is whether conservation managers should take such high risks of losing irreplaceable areas of beautiful natural wilderness forever, based on these ideas that are not firmly supported by scientific evidence gathered over the longer term. Is it fair to current and future human generations, as well as to the diverse species of living beings involved to adopt management policies that might lead to irreparable damage of conservation areas or cause nonreversible harm to wildlife populations?

Unexpected changes in climate and weather patterns, and the impact on food resources are some of the features that humans cannot control or always manage efficiently. The comment of Sheldrick (1980:88-89) regarding the devastating outcome of a severe drought and the attempts of an elephant cow to comfort young orphaned elephants serves as an example:

Droughts have always been and always will be a feature of areas of such marginal rainfall such as Tsavo: they are something ordained by nature which lies beyond the control of man. They may even be necessary in arid lands to trim populations of large mammals such as elephants to the carrying capacity of the land and permit the large-scale regeneration of the nyika's scrubby bush. Nothing is ever static in nature; it swings back and forth like the pendulum of a giant clock that gauges time not in tens but in hundreds of years ... If (the rains) did not come at all or fell so intermittently, that the first flush of green withered before the plants could cast their seeds, then the elephants, with their gigantic appetites and inefficient digestions were the first to suffer. But never had they been in such dire straits as during those six long, harsh years of the great drought. They died in their hundreds.

During this time of great suffering and sorrow, baby elephants were being orphaned nearly every day as mothers succumbed to the effects of malnutrition. From Eleanor's large heart flowed the boundless sympathy and comfort that an elephant can give in such generous measure, and which she lavished on one drought-stricken orphan after another whenever they were brought back by the Field Force. 
Unhappily, by the time most of them arrived back they were usually already too far gone to be saved, and the shock of capture proved fatal, but we, and Eleanor, always did our best just the same, and were kept very busy. However, when despite our efforts one baby elephant after another collapsed and died, Eleanor sorrowed so sorely that we became worried about subjecting her to so much mental anguish, for she was showing signs of becoming neurotic, and even began to lose condition. Quite obviously, she came to associate lying down with death, and because of this did not like to see any of her charges lying down, even for a rest. Dashing over immediately, she would haul them back on to their feet to satisfy herself that they were not about to die as had so many others recently. Consequently, after a while, all her charges began to suffer from lack of sleep, going about in a daze like zombies.

Is it fair to elephants to casually allow their numbers to increase to such an extent that a major once-in-a decade-or-two drought will trigger a population crash? For an elephant population to crash means that large numbers of elephants die of starvation. Some elephant lovers would rather see them die of starvation than have humans control their numbers through methods like culling. The crucial issue is whether elephants dying of starvation over a period of weeks and months suffer less than a herd of thirty elephants all being shot by a rifle from a helicopter within two or three minutes (Chadwick, 1992:431-432). Why is devastating long-term elephant suffering ending in a slow, painful death for some, and experiencing the painful deaths of kith and kin for others more acceptable than almost instantaneous death? This question is very important, as the crippling suffering is not only nature's doing by means of regularly occurring droughts. This suffering also results from human inaction and omission. If humans interfered in order to ensure that a conservation area had enough food available for its inhabitants to withstand the kind of drought that occurs only once every fifty years, that kind of intense pain and distress would have been avoided for large numbers of elephants (see Birkett, 2002:276-282). This point needs to be stressed, as culling is never to be viewed on its own, but must be judged in contrast to the consequences entailed by its alternatives. If the choice is to let nature be, then the long-term consequences of such choice must be justifiable as well.

A policy of environmental laissez faire, of letting nature be, rests on a huge mistaken assumption. The assumption is that beneficient 
natural processes operate at any level, regardless of the size of a conservation area. This assumption is incorrect. Some crucial natural processes operate at least partly at much larger scales, such as global warming and weather systems (EI Nino, for example) clearly illustrate. To let nature be might have been an appropriate environmental policy to protect all living beings on earth during those times, centuries ago, when a much smaller human population had minimal impact on the earth's environment and the inhabitants of its ecosystems. Those days are long gone. Ever since the discovery of fire and the development of technological skills to make weapons, humans have had an exponentially increasing impact on the earth's environment and its inhabitants. Humans have been hunters through millennia: at times ruthless, destructive hunters that have exterminated a variety of species. The acceleration of our exploitation of wildlife throughout the 19th and 20th centuries, our increased occupation of land through our rapidly growing numbers, and our destruction of the environment through pollution, deforestation and global warming are major factors depriving wildlife of its traditional safe havens and sanctuaries in unspoilt wilderness areas.

The effects humans have had on the environment over the last two centuries imply that wilderness areas as habitat for wildlife - and especially for elephants - have shrunk dramatically. Space for those species of wildlife that cannot easily co-exist with humans is not available outside many conservation areas anymore. Conservation areas have become the safe places, the sanctuaries of wildlife. They are indeed artificial human constructions that form small islands of wilderness amidst the African lake of human settlements that drive elephants and other big game out, as elephants especially compete with agricultural activities or endanger human lives (see Chadwick, 1992:40). Scientists working on the so-called elephant problem more often than not do not show sufficient awareness of the exponential increase of the human population in Africa over the past two centuries, with the associated diminishing size of land available for wildlife. The extent to which natural ecological processes have been curtailed, constrained, and diminished by human beings over the last hundred years still awaits detailed investigation and explanation. Whether we can still speak of "natural processes" in Africa's small areas of land available for conservation is a decisive factor in debates about elephants, but a factor as yet poorly understood.

As human constructions, conservation areas have fences to delineate their boundaries. These fences can consist of wire, electric 
cables, or human settlements. Elephants leave a territory when human density exceeds 16 humans per square kilometer (Du Toit, 2002:1412). Conservation areas are thus heavily influenced by human settlements surrounding them, even in some of the supposedly most natural conservation areas without any fences, like Chobe National Park in northern Botswana (see Cumming \& Cumming, 2003:566). Some rivers running through conservation areas are used, abused, and polluted by humans where those rivers flow through their agricultural land or urban areas before these rivers enter conservation areas (Whyte, 2001:9). Cattle come in contact with animals like buffalo and transmit diseases like bovine TB that spread through some wildlife populations like wildfire. Humans spread exotic plant material that rivers, birds, or winds carry into wilderness areas where those plants might choke vulnerable, endangered indigenous species. Conservation areas in Africa are thus invariably influenced by human beings to a greater or lesser extent - the issue that needs to be addressed is to what extent humans are detrimentally influencing the natural ecological processes in a specific conservation area.

Why and how had these artificial human constructions, called conservation areas or game reserves, been created? In Africa, most of these conservation areas were initially created to protect wilderness areas and to safeguard species of African wildlife from extinction. Hunting by so-called great white (European) hunters led to the extinction of some species, like the Cape quagga. In proclaiming these conservation areas, governments removed the human settlements in those areas. In most cases these people had been living in those areas for centuries, where they made a living that had minimal impact on the environment. Whilst in most cases they hunted wildlife for food, they did so in ways that kept wildlife populations in check rather than decimating the hunted game like the European hunters did in the colonies their governments ruled by force.

Once these indigenous people were removed from conservation areas, mostly without compensation, a new kind of human presence invaded these wilderness areas. The people in charge of conservation areas and providing services to tourists live permanently in conservation areas. A constant flow of tourists in motor vehicles has established yet another kind of human presence. Contemporary conservation areas are not pristine wilderness areas without human presence. Motor vehicles need roads. Roads provide easier routes for large animals than struggling through the sometimes dense 
African bush. Dust roads interfere in nature as the dust collects on plants, especially grass, alongside the road. Tarred roads are slippery for some larger mammals, making such roads favourite hunting grounds for some lions.

The important point is that conservation areas are not part of vast open expanses on the African continent where no humans, or only small groups of humans with low environmental impact, occur. Conservation areas are surrounded by human settlements and closed off from the wider areas and open spaces that were available in earlier times. If the public is given access to conservation areas, as invariably happens, game reserves are significantly interfered with through the high-impact presence of humans caused by their vehicles and their consumption of food and water. The infrastructure required for vehicles (roads and fuel) and consumption (shops, refuse removal, water and sewerage systems) have a significant impact on wilderness areas. The result of all these different kinds of interference on a local and regional scale is that some larger scale ecological processes do not operate as we suspect they did two or more centuries ago. If we do not intervene to correct unacceptable human influences that disturb nature's processes, we will merely be condoning human intervention and interference that occur anyway.

There seems to be some kind of inverse proportional relationship at work regarding the need for human intervention in conservation areas. There is a greater chance of a more complete package of natural ecological processes still operative that requires little or no human intervention the larger the conservation area and its associated semi-wilderness neighbouring areas are. In smaller conservation areas less natural ecological processes might be at work requiring more human intervention. With zoo enclosures, for instance, elephants require human interference at almost impossibly high levels to provide elephants with any kind of "natural life." Although this inverse proportionality is merely speculative, it serves to illustrate the point that human occupation of land formerly available for wildlife in Africa has created massive challenges to manage conservation areas in ways that keep natural ecological processes optimally intact.

Should we condone the irresponsibility of some humans that led to exotic plants invading conservation areas? And should we allow those plants to squash the indigenous plants that host many insects and birds? Should veterinarians do nothing when cattle diseases carried by imported cattle from Europe are transferred to buffalo at boundary fences and eventually threaten to wipe out the lion 
population of the Kruger National Park, for example? Does the idea that nature must take its course in this case dictate that nothing needs to be done? I doubt that. To let nature take its course rather implies doing research to develop vaccines so as to get rid of such diseases and to find solutions to get rid of exotic, problematic plants that have been imported from other continents by irresponsible humans. In such cases human intervention keeps nature on track. Intervention corrects the follies and mistakes humans make that can upset delicate ecosystems that nature lovers want to observe functioning as they functioned millions of years ago.

Can this justification of intervention also be applied to the management of elephants? Nobody really knows how elephant numbers were kept in check by nature when humans only had a minimal impact on their environment (Scmidtz \& Willott, 2002:16). We do know that many human communities in Africa and Asia hunted elephants, as humans hunted mammoths and mastodons virtually to extinction in North America, Europe, and Asia (see Owen-Smith, 1988:296). Whether elephants died of starvation during droughts, whether they migrated to areas with no elephants, whether they suffered from disease or predation, nobody really knows (Sukumar, 2003:374; Owen-Smith1988:2). These phenomena imply that if we choose to intervene, we must find information and justification for such intervention from sources other than a romanticised past.

\section{Conclusion 2:}

Humans have already massively interfered with nature and must take responsibility for this interference. We thus ought to interfere responsibly to conserve wilderness areas for future generations in as natural a state as possible. Malevolent human interference in nature has become so prevalent that humans must now interfere benevolently so as to "let nature be". The aim is to protect and conserve nature's workings in the earth's biosphere through all the various ecosystems. This aim implies that environmental ethics must give priority to a holistic approach to the conservation of the earth's biosphere and its constituent elements.

\section{2 "Animals have rights and thus no elephant may be interfered with"}

Many of the harshest critics of human interference in the lives of elephants, especially by means of culling, are referred to as animal- 
rights activists or animal-welfare activists. Do animals really have rights that humans must respect at all times? If so, who have assigned them their rights and why should humans refrain from violating these rights? Or should we perhaps argue that all sentient beings have interests that humans ought to respect to the degree that those beings can experience welfare, i.e. pleasure and satisfaction or pain and distress? If the interests and rights of individual animals have to be taken into account, should these interests and rights get priority above the well-being of ecosystems and species?

\subsubsection{Regan's deontological individualism}

Tom Regan (1983) is regarded as champion of the idea that animals have rights which humans must respect (see also Cohen \& Regan, 2001). Regan's uncompromising stance is that many living beings are similar to humans as they possess mental capacities and can experience their lives in terms of better or worse welfare. Such animals are subjects-of-a-life and they thus have inherent value. Thus, animals must be treated respectfully as rights-holders that have the same moral status as humans. Respectful treatment implies that such beings may not be killed, their bodies may not be invaded or injured, and their choices may not be restricted nor their freedom limited. Regan strongly rejects all utilitarian positions as such views cannot protect innocent individual animals from being sacrificed for the benefit of others whose interests count more (see Sagoff, 2002:42). Regan emphatically rejects the killing of any rights-holder and strengthens his position by saying that killing is unacceptable regardless of the consequences for others.

When he discusses wildlife, Regan often states his view simply as "let them be!" (Regan, 1983:357, 361). He refuses to see wildlife as a natural resource available for human benefit and recommends that wildlife managers should aim to keep "human predators out of their affairs" (Regan, 1983:357). I doubt whether Regan's views on animal rights can be applied so simply to conservation dilemmas. He touches on such issues briefly, but does not highlight the full implications of his view that all individual animals have rights that need almost absolute protection. Applied to the issue of controlling elephant numbers, one can usefully extend his views by taking a cue from his discussion of what is ethically acceptable when a rabid dog attacks you in your backyard (Regan, 1983:296). Although he reiterates his position that animals can do no moral wrong, in this case the dog is a threat to our bodily integrity and maybe even our life. We can thus defend ourselves and harm the dog in the process 
(Regan, 1983:296). What Regan does here is to weigh the rights of humans, whom the dog might violate, against the rights of the dog as aggressor that intends bodily harm to a fellow animal (the human). The rights of the victim thus trump the rights of the aggressor through legitimate self-defense.

Let us assume for the sake of argument that Regan's view on animal rights is generally accepted as true and correct. If individual elephants have rights and so too millions of individual insects, reptiles, birds, mammals, and amphibians qualify as rights-holders, how are we going to solve the ensuing complex conflict of rights when elephants destroy the habitat and thus endanger the livelihood of millions of other rights-holders? (see Cumming \& Cumming, 2003:561). Animals cannot manage and administer their own rights under the best of circumstances, thus needing humans to assist them. If humans have to solve this problem in terms of animal rights, then we should interfere in this conflict of rights to life. Or could an animal-rights supporter be so callous and insensitive to say that millions of living beings can be allowed to die in the name of "letting nature be", but not one animal may die as food for humans or in service of medical research to save humans (and animals) from devastating illness and disease? Perhaps culling elephants with the explicit motive of removing excess numbers to protect the habitat for millions of living beings seems more in line with an animal-rights approach than merely letting nature be?

\subsubsection{Singer's consequentialist individualism}

Peter Singer offers an alternative justification for placing the interests of animals much higher on our human list of priorities. Singer makes the apparently controversial claim that humans have no special place in nature and cannot claim any superior position to any other animal in any process of ethical decision making. This strong claim is qualified by other aspects of his theory (Singer, 1985:6). Singer counts all beings as morally relevant and able to experience pain and distress or enjoy things and have pleasure. His view acknowledges that taking a human life can be worse than killing a snake. The reasons are that humans have more complex and sophisticated experiences of pain and pleasure and humans have more complex mental lives that include pasts and futures (Singer, 1985:9). Thus, humans' interests weigh more and count for more than the interests of a snake, for example. Humans suffer more intensely than snakes. If suffering can be measured in units, one could thus say that humans experience more units of suffering 
than snakes and therefore the suffering of an individual human will outweigh the suffering of one individual snake by far.

In a National Geographic documentary, "Giants of Etosha," the following story is told.

Ginger Mauney has observed how a matriarch called Knobnose has lost two calves in quick succession through anthrax. Knobnose was devastated. She left the herd and wandered aimlessly for several weeks. Ginger has never heard of a matriarch leaving her herd and saw this as an indication of the depth of her pain. When Knobnose later rejoined the herd, Ginger saw that she remained isolated in her grief. When Ginger next saw the herd, Doughnut was the new matriarch leading them.

At a large gathering of elephant herds at a waterhole, hundreds of elephants were milling around. Only Knobhouse and her herd acknowledge the bones of a small elephant lying there. This spot is a gravesite of one of Knobnose's calves. Knobnose and her herd engage in what seems a silent ritual of mourning. Listening to tapes afterwards, Ginger hears the elephants' private language of grief conducted in infrasound during this moving ceremony. When the other elephants move away, it is clear that the time of mourning was too short for Knobnose. She lingers and whispers to the bones once more. Again Doughnut is the one leading the herd away.

When the herd re-appears in central Etosha after migrating towards the north for a few months, Knobnose leads them. She looks strong and re-assured and has a newborn calf with her.

If Singer's intuitively plausible views are applied to the elephant problem, the interests of an individual elephant will outweigh the interests of most other individual animals belonging to species other than homo sapiens. Elephants would have a moral standing lower than humans, but higher than most other animals. Some reasons for this view include the following. Elephants have a remarkable inner life and emotions. These highly intelligent animals with strong social bonds exhibit a wide range of emotions. The way they deal with death by means of covering carcasses and smelling the carcasses, as well as ongoing mourning, is moving (Payne, 2003:82, 83). However, despite the moral standing of individual elephants and 
their species, Singer does not intend his utilitarian ethics to be applied in individualistic fashion. When a conservation area has an overpopulation of elephants that are destroying the habitat of other species and themselves, a careful weighing of the interests of different forms of life has to be done. The issue is to determine the effect that the consequences of different decisions will have for all parties involved. The interests of all individual elephants, millions of other living beings, tourists, wildlife managers, and all other stakeholders must be weighed against one another. I am doubtful whether Singer's utilitarian ethics that treats animals as equals will recommend that no interference is the only justifiable option. There are too many other animals that might lose their lives and, in some cases, even whole species might be wiped off that part of the face of the earth. Singer's utilitarianism would definitely require some kind of intervention in favour of the millions of animals with threatened livelihoods. Some kind of management intervention, such as culling, translocation, or contraception will be justified if all interests are fairly added up.

Although the rights-based and interest-based ethics presented by Regan and Singer were not specifically developed as conservation ethics, their views alert us to the moral responsibility humans have to treat individual animals humanely. Furthermore, we must combine Regan and Singer's insights with those produced by elephant researchers like lan Douglas-Hamilton, Cynthia Moss (1988 \& 1992), Joyce Pool and Katy Payne (1998). These researchers use social scientific methods akin to participant observation originally developed in anthropology. Regan and Singer urge us to take note of the wonder of elephants as agents and these elephant researchers enable us to do just that.

Elephant researchers have convincingly demonstrated that individual elephants are agents, sources of self-originating activities (Taylor, 2002:89). They have sophisticated bodily processes that are capable of transforming atoms and molecules into highly complex living structures that form a living, sentient being, with an instinct and capacity for survival. Elephants have senses similar to human beings: their eyesight might be worse than ours, but their sense of hearing and sense of smell are far better than what we possess. They can experience a range of emotions, of which playfulness and "being silly" in particular amuse us, their mourning the loss of family and friends moves us, and their gentle loving care for their young endears them to us (see Moss 1988 \& 1992). Elephants are majestic creatures that inspire awe for their huge size and enormous 
strength. They engender our sympathy and love for those qualities that made ascriptions such as "intelligent" and "gentle giants" true. As humans, we have to treat them according to these special qualities, which make them so similar to us.

Anyone who doubts that an elephant can be a subject-of-a-life and can exhibit the most amazing characteristics similar to those of human beings, must read the story of Ely, as told by Cynthia Moss and her research associates (Moss, 1992:64-74). This elephant calf, Ely, was born with stiff carpal joints, that caused him to walk on his knees, as it were. Moss thought he was going to die, but through what Moss and her associates describe as "the calf's gallant struggles" and his "display of sheer determination and guts", the calf managed to teach himself to walk properly. Through the many hours of his struggle, his mother and sister calmly and gently assisted him. In the words of one of the research associates:

One scene stays vividly in my mind. The threesome were heading towards us through the picturesque palms of Ol Tukai Orok. As the two older elephants walked, they continually turned to look back at the calf which was shuffling along behind. Every few feet they stopped and waited for him to catch up before moving on. Their progress was very slow, but they did not show any signs of impatience with the calf. It was a poignant sight and highlighted the incredible, caring nature of these animals (Moss, 1992:72).

Having pointed to the similarities between humans and elephants that create special bonds, we should not ignore the enormous differences between the two species. Although elephants can destroy us through their enormous physical power in any one-onone fight, humans are the dominating species that control so much of the lives of elephants. Perhaps the most important difference between the two species is the fact that elephants cannot call a meeting and discuss the problems their feeding habits create for other species. They cannot come up with a plan to deal appropriately with such an issue. We must do it for them. Elephants do not have our highly sophisticated communication skills, including natural and symbolic languages. They do not have our strong moral sense, nor our amazing organisational capacities. Elephants cannot transform natural resources into useful products such as computers like we can, and their impact on their environment is dwarfed by our impact. Our capacities for suffering and mourning the loss of our dead manifest in far more complex ways than similar capacities do in elephant society. The interests of elephants cannot have the 
same weight as those of humans, as our complexities in terms of features we define as relevant to moral standing far outstrip theirs.

Elephants are also not the only animals with special characteristics that we judge to be amazing, although they might be one of the most special non-human beings on earth. Many animal species have special characteristics that we value or admire, or qualities that make them unique, appreciable, and astounding. For example, we prize owls for eyesight in the dark, their sharp hearing, and their stealth flying. We are amazed by the navigational skills of pigeons and marine turtles. Dogs are highly valued animals for their acute sense of smell, their ability to be trained for specialist functions to assist the police, emergency services, and disabled people, their sensitivity to human emotions, and their companionship coupled with immense loyalty. We admire and fear lions for their regal demeanour, strength, ferociousness, and their hunting prowess. The differences in the complexity of mental life between humans and elephants are perhaps much more than the differences between elephants and owls, dogs, or lions. There seems to be no convincing reason why elephants should deserve a moral status similar to humans, as they are much closer to other animals than to humans. They do, however, deserve a special moral status within the animal kingdom, as they have some of the most complex sets of behaviour and intricate inner lives of all animals.

\section{Conclusion 3:}

Elephants are very special animals (mammals) that deserve treatment with respect. They are, however, not rights-bearers at the same level as human beings and they are not necessarily deserving much more respect than dogs or lions. Although we must take Singer's consequentialist individualist environmental ethics seriously, the interests of individual animals cannot outweigh our concern for the ecosystems and biodiversity of the earth's biosphere.

\section{3 "Ban human utilisation of conservation areas"}

Opponents of human interference to control elephant populations often associate culling with the commercial use and exploitation of wilderness areas and the wildlife they contain. They surely have reason to think so - the culling operations in the Kruger National Park (1967-1994) and at Luangwa in Zambia (1967-1969) both had abattoirs that processed meat, hides, and ivory for commercial purposes (see Hanks, 1979). Opponents of this practice find the 
idea abhorrent that conservation must pay its way through utilising natural resources by means of regular harvesting of wildlife (Hanks, 1979:165). Whether harvesting takes place by means of culling excess animals or issuing hunting licenses, the whole idea of a conservation area conforming to the economic logic of cattle ranching, seems repulsive (Ginsberg, 2002:1185; Du Toit, 2002: 1403-1416). The reasons behind this feeling against utilisation are that human interests stand paramount in determining the value of wildlife, with the implication that whatever humans do not find valuable, can be neglected, abandoned, or wasted. People against this kind of harvesting, or sustainable utilisation of wildlife resources, try to articulate an intrinsic value for conservation areas, assigning value to them that is independent of human concerns and interests.

Can conservation areas escape being used by human beings? In a sense that is impossible. Conservation areas and game reserves exist as open spaces dedicated to some form of conservation by the grace of human beings, mostly through the institutions of governments. Conservation areas and game reserves proclaimed as wilderness areas, national parks or provincial reserves, or private game reserves and game farms, exist and operate within the framework of a political system and its associated constitution and laws. They are often proclaimed in terms of specific laws. Governments have environmental agencies and bureaucracies charged with the management, development, and extension of such areas. To have conservation areas properly managed and protected, to increase the number of habitats, landscapes, and ecosystems to be preserved, and to ensure appropriate conservation policies, require political action to lobby, pressurise, and influence governmental policy makers. To do so successfully, conservation areas and game reserves must be of some use to the citizens of a country and concerned, interested parties from elsewhere as well (Regenstein, 1985:132).

\subsubsection{The goal and purpose of conservation areas}

What is the goal and purpose of conservation areas? I want to argue that the conservation of natural world diversity should be the broad, overarching goal of the conservation of wilderness areas in any country. The concept biodiversity is commonly used to refer to the goal of conservation (see Holmes Rolston III, 2002:38). Although biodiversity is often employed with wider meanings than the mere conservation of life (bio-) forms (Whyte, Biggs, Gaylard, \& Braack, 1999:113), I prefer the term natural world diversity which can more easily include all forms of life, as well as landscapes, places of 
geological interest, ecological processes, water systems, ecosystems, and so on.

Conservation in national parks and wilderness areas should be comprehensive, with the goal to protect the full scope of natural world diversities. This approach implies that all aspects of conservation areas should be protected so as to allow and enable nature to function, as far as possible, on its own without human interference or even without benevolent human intervention. These special conservation areas are to be treated as the heritage of the citizens of the world and should be sanctuaries where humans do not kill and destroy any kind of life. Conservation areas in Africa should exhibit the beauty and magnificence of the African wilderness as it has developed and changed throughout the centuries. These areas should have limited human presence and even less human interference, so as to allow natural ecological processes to function as they did for millennia. These places should be free from all forms of human domination, exploitation, and oppression.

Such conservation areas provide opportunities to establish different "biocentric" or "ecocentric" "worlds" where natural world diversity flourishes and free animals pursue their interests as they see fit within their preferred habitats. Such "worlds" can allow evolutionary processes to follow their slow, mysterious ways. Ecotourists should behave like visitors and guests who show deep respect for the "citizens" of these "worlds." They should know and appreciate the fact that no conservation area is either a cattle ranch or a zoo. In these areas nature must follow its course and human interests must be subservient to the dictates of the wilderness. Ecotourists in these "worlds" can imagine themselves entering past worlds, worlds similar to the ones in which humans first evolved thousands of years ago and akin to those in which our early hunter-gatherer ancestors survived for millennia.

\subsubsection{Four arguments for the conservation of natural world diversity}

Why should politicians be convinced that this idea of the conservation of natural world diversity would best serve the interests of their electorate? I want to present four arguments for the conservation of natural world diversity.

The arguments for the conservation of natural world diversity appeal to two ideas. One idea is that conservation areas can have multiple uses. The other idea is that conservation areas can induce complex 
and diverse human experiences in different individuals involved in a variety of activities.

\subsubsection{The deep appreciation argument}

I want to call the first argument for the conservation of natural world diversity, the deep appreciation argument. The manifestation of the diversity of the natural world brings us into contact with events and phenomena that are so much more than us, and which have been in existence and in the making for millions of years before we arrived as latecomers on planet earth, in terms of an evolutionary timescale. The diversity of the natural world confronts us with an awareness that we cannot create anything remotely similar, despite the scientific and technological brilliance of our species. The natural world overwhelms us by showing us life-forms more sophisticated in some ways than us, and thus we are left in awe of its wonders. Aldo Leopold (1981) best articulates this sense of wonder, reverence, and amazement in his wonderful book, $A$ sand county almanac. It makes sense that so many visitors to conservation areas have experiences of awe, wonder, and amazement. These experiences provide special ways of recreation and relaxation that give new perspectives on the nature and role of our species on earth.

Experiencing the amazing diversities of the natural world can also be humbling. In these conservation areas we get a faint inkling of the dangers and threats with which our ancestors lived. Without access to the tools created by our enormous scientific and technological capacities and skills, individual humans cannot roam around self-confidently in conservation areas as masters of the earth. Many living beings can kill or maim us if we move around in their territories without the usual human tools for protection (Chadwick, 1992:93). We often need to be reminded of our human vulnerability so as to experience ourselves as part and partner of the biotic community on earth. A situation as depicted below can perhaps illustrate our dependence on helping aids in appreciating nature:

'Where is the tape and microphone, Wolfgang? I can hear the Southern Boubou calling!'

'I don't know Lilly, we last used it to tape the Heuglin's Robin. Maybe it is next to the digital camera, or perhaps in the video camera's bag.' 
'OK, Wolfgang, I have found it. Now I can record the Southern Boubou's call!'

'I will check all the details of the Boubou on the laptop's Robert's programme while you are recording.'

'Wolfgang, before you do so, please take our book of trees and check whether the Boubou is sitting in a star chestnut.'

'OK, I'll do so if I can find the book amongst the mammal, reptile, and butterfly books! You better start recording or your Boubou will fly away. In the meantime I'll also reorganise our books and equipment!'”

\subsubsection{The interests of the current generation}

The value of the diversity of the natural world can also be argued by appealing to the interests of the current generation. To have such special experiences in conservation areas, citizens must have access to them. Not every citizen gets an opportunity to visit a prime national park regularly or even once in their lifetime, due to factors such as cost, availability, accessibility, and low income. Everyone alive now should have an opportunity to visit such places and experience nature in this special way, which reconnects us with our evolutionary history. For this reason citizens have a vested interest in ecotourism. Tourists typically want to see the charismatic megafauna (the big five and their associates), but they also want to observe the splendours of the rich diversity of the natural world of the African savannah. This diversity includes big and small mammals, plants, insects, birds, reptiles, amphibians, landscapes, scenic beauty, and majestic trees that are much older than humans. Tourists ought not to be deprived of observing and experiencing forests and woodlands in prime condition. They long to see this complex, comprehensive package at its winter's or summer's best. Perhaps not all tourists want to see all species, but they at least want to see their collection of favourites and know that the prerequisites for the survival and flourishing of these species are maintained in tact.

I find it particularly noteworthy that very few people champion the case of plants in the debate about the so-called elephant problem. For so many participants in this debate, plants can be destroyed at will by elephants, because supposedly plants can regenerate in a century or two. I find this attitude towards plants problematic. It might be that grasses and shrubs can regenerate in a relatively 
short period of time, but some trees take decades and even centuries to reach their prime. The trees of the African savanna can be enormously spectacular. lan J. Whyte is one conservationist clearly aware of the value of trees in relation to the value of elephants. He (Whyte, 2002: 299) says

... to stand under the canopy of a massive old baobab tree and to ponder a little on the age of such old giants, is an emotional experience of a different kind, but one which in its own way is no less soul stirring than that which may be gained from elephants. It is perhaps also their size which makes the initial impression, but the aura of age is tangible.

He also acknowledges baobabs as a "keystone species" in the light of their significant role in creating living space and survival opportunities for many other living beings (Whyte, 2002:299). For reasons like these, woodlands in prime condition need to be conserved as an example of what such woodlands can be like without severe utilisation caused by an overpopulation of large herbivores. The interests of elephants should not totally outweigh the beauty and value of the amazing variety of woodland species (Regenstein, 1985:130).

I honestly doubt that any tourist wants to see the starvation and horrific suffering of thousands of animals during a drought that results from human decisions that allowed large numbers of wildlife to deplete food resources. I also doubt that tourists want to observe devastated woodlands with the skeletal remains of once magnificent trees, which results from those same decisions. Such decisions have the consequence that wildlife runs out of food during serious droughts and thus destroys woodlands. If starvation happens during a once in lifetime drought (occurring once every fifty to hundred years) it might be understandable. If severe mass suffering of animals through starvation, however, occurs during a once-in-adecade drought, it will be far less acceptable. Furthermore, tourists do not want to feel threatened by any animals and feel unsafe in their cars. Aggressive elephants that dominate a conservation area through large numbers might pose serious threats. Tourists thus have an interest in preventing elephants from being made aggressive through trophy hunting or indiscriminate, badly planned culling. 


\section{Conclusion 4:}

We cannot ignore the interests of tourists, some of whom might only get one or two opportunities in a lifetime to experience the wonders of African wilderness areas at their best. For this reason conservation areas should be managed with the utmost care to portray natural world diversity at its best. Humans have strong interests in the conservation of both ecosystems and wilderness areas that portray part of our evolutionary history.

\subsubsection{The interests of future generations}

Future generations in three hundred years' time could expect that we have conserved the diversity of the natural world for them to enjoy, just as we can now be legitimately angry with previous generations for hunting certain species to extinction. The futuregenerations argument states that people in many different futures must have similar opportunities to ours to experience, observe, witness, and enjoy the world as it once consisted of a variety of wilderness areas, of which very few examples are now left. Once such areas are lost, they are gone forever. Most of the areas that remain today consist of extremely fragile landscapes that have not yet been dominated and affected by human interference or intervention. They consist of different "packages" of natural world diversities. Although fragile, in decades after destruction these landscapes are sometimes quite robust in terms of possibilities for long-term regeneration. However, this capacity for regeneration varies and some ecosystems (like forests) do not recover after destruction (Owen-Smith, 1988:279). Many conservation areas are priceless in terms of scenic beauty, but many are extremely vulnerable to the destructive potential of human power.

\subsubsection{The pragmatic argument}

There is a pragmatic argument that, in combination with the other arguments, supports the overall value that conservation areas have for political decision makers and their electorate. The pragmatic argument consists of two parts, based on the benefits we know conservation areas can have for us and those yet unknown benefits. Anyone familiar with the natural sciences knows that we do not fully understand the nature, functions, and workings of all aspects of the natural world. To neglect or destroy aspects of the amazing diversities of the natural world implies an arrogance to make and implement decisions about things we do not fully know and understand. Furthermore, allowing species to become extinct 
deprives future generations of opportunities to independently experience, observe, study, and understand aspects of the natural world based on what will be their vastly superior base of accumulated knowledge, bequeathed in part by us to them. So we have to protect all diversities of the natural world, even those ones we think we know and understand completely. Only then do we leave future generations the option of learning about certain life forms, phenomena, and events for the first time, or to revise what might prove to be our inaccurate or incomplete knowledge.

Man's intervention in nature and the killing or removing of one animal from its habitat have manifold consequences not always realised by us. The following incident illustrates that we do not always understand and calculate the outcome of every act of interference in the animal world:

Joshua senses that something is wrong with the truck. Its huge size makes it difficult to maneuver the vehicle through the small mountain pass near Hoedspruit. The huge bull elephant that has been captured earlier the morning in the KNP weighs more than seven tons. The elephant does not help Joshua at all - the bull constantly moves around from one side to the other. At the sharpest turn near the bottom of the pass the movement of the elephant is suddenly just too much for the truck. Joshua clings frantically to the steering wheel, but the truck runs off the road and crashes into a ditch. Involuntarily Joshua thinks: fortunately I was driving slowly; fortunately I did not sustain any injuries. His first concern is the elephant - Joshua gets out of the vehicle and inspects the elephant through the viewing holes in the truck. Oh dear, he thinks, the elephant is hurt. Fortunately the veterinarian in charge of the capture has just arrived on the scene. The vet is very upset about the injury and possible loss of a trophy bull. Immediately he tries to diagnose how serious the elephant has been hurt. In the meantime, a crowd of locals have gathered around the truck. They start singing with joy: they might have a feast tonight if this elephant dies!

No one can argue that we are clueless about the benefits some species of African wildlife can produce for humans. For thousands of years humans have roamed the plains and mountains of Africa in search for food among Africa's fauna and flora. No one really knows how big the impact of human hunting was on African wildlife, elephants included. What can be said for sure is that the impact was 
minimal and the use of African fauna as a food source was sustainable. If not, we would not have had reports from early European explorers describing Africa as a place "teeming with wildlife".

The advent of conservation areas and game reserves has stopped the descendants of these traditional Africans from engaging in traditional cultural practices to ensure their survival. They were removed from newly proclaimed conservation areas, excluded from their erstwhile hunting grounds, and those who crossed the boundaries to hunt as their ancestors did were - and are still persecuted as "poachers." Have these people been fairly treated? Their voices and concerns are not often heard and their case mostly appears as a few notes in the margins of the debates about the management of elephants. Perhaps their unfair treatment and the neglect of their interests are part of their unwillingness to support conservation. These people often legitimately regard conservation areas as their former homelands that provided them with livelihoods. They judge that colonial or independent governments have unjustly deprived them of access and ownership of these areas. Now these areas are playgrounds for the rich from which the people who ensured the survival of African wildlife over centuries through sustainable use derive no benefit. Many of these people living in poor communities around conservation areas - and hosts of their kin in urban areas - have become estranged from conservation efforts. Many conservationists judge that overcoming this estrangement is crucial for the long-term success of conservation in Africa (Weladji \& Tchamba, 2003:73; Buss, 1990:176).

African wildlife has been a major resource in the struggle for human survival on the African continent for centuries. Can it be used as a sustainable resource for fighting desperate human poverty in African countries? (Osborn \& Parker, 2003:73; Du Toit, 2002:1403-1416). Will it be ethically acceptable to use conservation areas not only for the purposes of ecotourism broadly described above, but also for hunting, culling, harvesting excess wildlife, thus, in short, for commercial exploitation? Several projects in different African countries have shown the idea to be viable if managed carefully (Bonner, 2002:320-329). The idea also makes sense, as many African savannah areas are by far more suitable for wildlife farming, than for cattle ranching or cash crops. If implemented on a large scale, much more land will become available for African wildlife, as has happened in South Africa's explosive development of 
commercial conservation for the purposes of ecotourism and sport hunting (Bulte \& Horan, 2003:110).

Many concerned wildlife enthusiasts immediately reject such proposals for sustainable use as ethically unacceptable. However, one must be careful not to reject such an idea out of hand. Most democratic societies experience reasonable moral pluralism, which means that over a range of issues, reasonable and morally mature adults make conflicting moral judgments on the same issue. Humans in democracies have learned to live with such deep moral differences about serious matters, such as abortion, by being tolerant towards one another and acknowledging that there are no universally applicable moral principles for some moral dilemmas (Willott \& Schmidtz, 2002:xx). Of course, there are certain fundamental moral values embodied in a society's conception of justice, such as the injunction not to kill fellow citizens. But even the detailed understanding and application of such moral values do not necessarily rest on full consensus, as can be seen in controversies about whether the right to life can be squared with the death penalty. Thus, if we live in a human world where we have reasonable differences about serious moral issues (see Gutmann \& Thompson, 1996), then can those of us whose personal morality does not allow hunting, rejects eating the carcasses of wildlife, and disapproves of animals being killed for human purposes, have a right to legislate for those of a different opinion? (see Schmidtz, 1997:327-329).

One must note that a vast majority of people accept the use of cattle, sheep, and pigs as excellent nutrition for human beings. I am not aware of any particular reasons why these commercially used animals should have much less of a moral status than most species of African wildlife. This state of affairs implies that rejecting commercial use of African wildlife as a sustainable natural resource for Africans to better their lives might be labelled as a case of cultural-ethical imperialism. Do rich, privileged environmental activists - who can afford a healthy vegetarian diet (or neatly packaged meat from a supermarket) - have the right to impose their cultural and personal ethical views about deeply controversial moral issues of hunting and eating meat on poor rural peasants with centuries-old traditions of sustainable use of wildlife?

Many Westerners and Africans of European origin cannot claim that their ancestors have a history of utilising African, American or European wildlife in similarly sustainable ways. European and American histories on many continents testify to their unsustainable practices: they have hunted many species of wildlife to extinction on 
their own continents (Gröning, 1999:444) and Europeans almost did the same in colonies on the African continent through large-scale slaughter of African wildlife by the great white hunters of the 19th and 20th centuries (Hanks, 1979:14). Thus, the credibility of these people is low in terms of their own history of wildlife utilisation and also because these nations are still major consumers of the meat of domestic animals. Nelson Mandela rightly said that the issues of culling and natural resource utilisation in Africa are ones that Africans will have to resolve for themselves, whilst still taking into account stakeholders on the African continent and further afield (Mandela, 1995:24-25).

If one takes the claims of people who have lived with African wildlife for centuries seriously, then the idea of a morally pluralist world opens the possibility for legitimate use of elephants through culling and hunting. I do, however, believe there might be good moral arguments that restrict both these options.

\section{Conclusion 5:}

We cannot ignore the interests of people living next to wildlife sanctuaries; nor their traditional lifestyles, the history of their neglect by many successive governments, or their exploitation through the expropriation of their land for conservation purposes. The legitimacy of conservation purposes and efforts can be established partly through benefiting the people most closely affected by conservation in their daily lives, those who often bear the cost of conservation by living in fear of African wildlife crossing boundaries to raid their crops, kill their cattle, or harass and kill them or their kin. Whether these benefits come through ecotourism, hunting, or through culling must be decided in the light of local circumstances and specific cultural values.

\section{Do we have a case for human intervention in elephant lives in conservation areas?}

In this article I have tried to establish arguments to justify careful and caring human intervention in conservation areas, which might include managing large numbers of elephants that are judged to be overpopulated. The argument consists of the following parts:

\section{- We ought to intervene responsibly}

Humans have already massively interfered with nature and must take responsibility for this interference; therefore we ought to 
intervene responsibly to conserve wilderness areas in as natural a state as possible for future generations. Malevolent human interference in nature has become so prevalent that humans must now intervene benevolently so as to "let nature be". Human intervention can be justified in terms of a fundamental commitment to respect the earth's biosphere and the natural ecological processes it contains. Limited management interventions in conservation areas thus should aim to reverse or neutralise any kind of human interference that obstructs, limits, or disables natural ecological processes. This commitment leads to a holistic environmental ethics that gives priority to the conservation of all factors that make life possible on earth.

\section{- Humans have a moral responsibility to treat individual animals humanely}

Animals ought to be treated as agents that possess inner lives of greater or lesser complexity. Though they have different levels of moral standing, they should be treated with respect to preserve their lives. Human interference in nature often leads to conflicts of interests between different kinds and numbers of individual animals. The elephant problem is a prime example. In such cases humans must intervene in a fair way to promote the diversity of the natural world, and the interests of all living beings should appropriately be weighed. Humans have a moral responsibility to treat individual animals humanely.

This commitment justifies an individualist consequentialist environmental ethics that alerts people to their responsibility to treat animals with respect, as so many animals have amazing mental lives and unquestionable capacities to experience pain and suffering. Elephants deserve a special moral status within the animal kingdom, as they have some of the most complex sets of behaviour and intricate inner lives of all animals. We have to treat them according to these special qualities, which make them so similar to us. Elephants as the largest land animals are very special mammals that deserve to be treated with respect.

\section{- The interests of elephants cannot have the same weight as those of humans}

There seems to be no convincing reason why elephants should deserve a moral status similar to humans, as they are much closer to other animals than to humans. The interests of elephants cannot have the same weight as those of humans, as our complexities in terms of features we define as relevant to moral standing far outstrip 
theirs. They are not rights-bearers at the same level as human beings. Although elephants possibly deserve one of the highest moral standings amongst non-human beings, they do not necessarily deserve much more respect than dolphins, dogs, or lions. Elephants are thus not the only animals with special characteristics that we humans judge to be amazing, but they are some of the most special non-human beings on earth.

\section{- "Human beings responsibly first, then the interests of other higher beings a close second"}

If we assign the highest moral standing by far to human beings, then we must say, "Human beings responsibly first, then the interests of other higher beings a close second." We cannot ignore the interests of people living next to wildlife sanctuaries; nor their traditional lifestyles, the history of their neglect by many successive governments, or their exploitation through the expropriation of their land for conservation purposes. We can also not ignore the injustices committed against people who were removed from land so as to establish conservation areas.

\section{- Be tolerant towards others with reasonable differences about moral issues}

The legitimacy of conservation purposes and efforts can be established partly through benefiting the people most closely affected by conservation in their daily lives, those who often bear the cost of conservation by living in fear of African wildlife crossing boundaries to raid their crops, kill their cattle, or harass and kill their kith and kin. Whether such benefits come through ecotourism, hunting, or through culling must be decided in the light of local circumstances and specific cultural values. Although many concerned wildlife enthusiasts will immediately reject such proposals as ethically unacceptable, they need to be tolerant towards others with whom they have reasonable moral differences about serious moral issues, such as hunting animals, eating the carcasses of wildlife, and killing wildlife for human purposes.

\section{- Conserve natural world diversity}

The conservation of natural world diversity should be the broad, overarching goal of the conservation of wilderness areas in any country. These areas should be available to citizens to provide them with experiences of awe and amazement at the wonders of pristine African wilderness areas at their best. Everyone alive now should have an opportunity to visit such places and to observe the 
splendour of the rich diversities of the natural world of the African mountains, plains, and savannah that reconnect us with our evolutionary history.

\section{- People in many different futures must have opportunities similar to ours}

Not only people alive now should have these opportunities, but people in many different futures must have opportunities similar to ours to experience, observe, witness, and enjoy the world as it once consisted of a variety of pristine, wilderness areas, of which very few examples are left. Future generations should also not be deprived of opportunities to independently experience, observe, study, and understand aspects of the natural world diversities based on what will be their vastly superior base of accumulated knowledge, bequeathed in part by us to them.

\section{- We do not yet fully understand all aspects of the natural world}

There is no doubt that we do not yet fully understand the nature, functions, and workings of all aspects of the natural world. To neglect or destroy aspects of the amazing diversities of the natural world implies an arrogance to make and implement decisions about things we do not fully know and understand.

If humans may indeed legitimately intervene in conservation areas to let nature be, to protect the lives of all the diverse individual animals under their care, and to conserve the amazing diversities of the natural word, then the management of elephants is legitimate as part of the conservation of natural world diversities. How to determine whether management options available for dealing with an overpopulation of elephants are ethical, is the topic of another essay.

\section{List of references}

BIRKETT, ALAN. 2002. The impact of giraffe, rhino and elephant on the habitat of a black rhino sanctuary in Kenya. African Journal of Ecology, 40(3):276282.

BONNER, R. 2002. At the hand of man: peril and hope for African wildlife. (In Schmidtz, D. \& Willott. E. Environmental ethics: what really matters, what really works. New York: Oxford University Press. p. 306-319.)

BULTE, E.H. \&. HORAN, R.D. 2003. Habitat conservation, wildlife extraction and agricultural expansion. Journal of Environmental Economics and Management, 45:109-127. 
BUSS, I.O. 1990. Elephant life: fifteen years of high population density. Ames: lowa State University Press.

CHADWICK, D.H. 1992. The fate of the elephant. San Francisco: Sierra Club Books.

COHEN, C. \& REGAN, T. 2001. The animal rights debate. Lanham: Rowman \& Littlefield.

CUMMING, D.H.M. \& CUMMING, G.S. 2003. Ungulate community structure and ecological processes: body size, hoof area and trampling in African savannas. Oecologica, 134:560-568.

DU TOIT, J.T. 2002. Wildlife harvesting guidelines for community-based wildlife management: a Southern African perspective. Biodiversity and Conservation, 11:1403-1416.

ELLIOT, R. 1991. Environmental ethics. (In Singer, P., ed. A companion to ethics. Oxford: Blackwell. p. 284-293.) (Blackwell Companions to Philosophy.)

GILLSON, L. \& LINDSAY, K. 2003. Ivory and ecology - changing perspectives on elephant management and the international trade in ivory. Environmental Science and Policy, 6:411-6419.

GINSBERG, J. 2002. Cites at 30, or 40. Conservation Biology, 16(5):11841191.

GRÖNING, K. (with text by SALLER, M.) 1999. Elephants: a cultural and natural history. s.l.: Könemann Verlagsgesellschaft.

GUTMANN, A. \& THOMPSON, D. 1996. Democracy and disagreement. Cambridge: Harvard University Press.

HANKS, J. 1979. A struggle for survival: the elephant problem. Cape Town: Struik.

LEOPOLD, A. 1981. A sand county almanac. Oxford: Oxford University Press.

LEUTHOLD, W. 1996. Recovery of woody vegetation in Tsavo National Park. African Journal of Ecology, 34:101-112.

MANDELA, N. 1995. Elephant cull in the Kruger National Park. SA Wild en Jag: 24-25, Oct.-Dec.

MAPAURE, I.N. \& CAMPBELL, B.M. 2002. Changes in miombo woodland cover in and around Sengwa wildlife research area, Zimbabwe, in relation to elephants and fire. African Journal of Ecology, 40:212-219.

MOSS, C. 1988. Elephant memories: thirteen years in the life of an elephant family. London: Elm Tree Books.

MOSS, C. 1992. Echo of the elephants: the story of an elephant family. London: BBC Books.

MOSUGELO, D.K., MOE, S.R., RINGROSE, S. \& NELLEMANN, C. 2002. Vegetation changes during a 36-year period in northern Chobe National Park, Botswana. African Journal of Ecology, 40:232-240.

OSBORN, F.V. \& PARKER, G.E. 2003. Linking two elephant refuges with a corridor in the communal lands of Zimbabwe. African Journal of Ecology, 41:68-74.

OWEN-SMITH, R N. 1988. Megaherbivores: the influence of very large size on ecology. Cambridge: Cambridge University Press.

PAYNE, K. 1998. Silent thunder: in the presence of elephants. New York: Penguin Books. 
PAYNE K. 2003. Sources of social complexity in three elephant species. (In De Waal, F. \& B.M. \& Tyack, P.L. Animal social complexity: intelligence, culture, and individualized societies. Cambridge: Harvard University Press. p. 58-85.)

REGAN, T. 1983. The case for animal rights. London: Routledge \& Kegan Paul. REGENSTEIN, L. 1985. Animal rights, endangered species and human survival. (In Singer, P., ed. In defense of animals. New York: Blackwell. p. 118-132.)

ROLSTON III, H. 2002. Values in and duties to the natural world. (In Schmidtz, D. \& Willott, E. Environmental ethics: what really matters, what really works. New York: Oxford University Press. p. 33-38.)

SAGOFF, M. 2002. Animal liberation and environmental ethics: bad marriage, quick divorce. (In Schmidtz, D. \& Willott, E. Environmental ethics: what really matters, what really works. New York: Oxford University Press. p. 38-44.)

SCHMIDTZ, D. 1997. When preservationism doesn't preserve. Environmental Values, 6(3):327-339.

SCHMIDTZ, D. \& WILLOTT, E. 2002. Environmental ethics: what really matters, what really works., New York: Oxford University Press.

SHELDRICK, D. 1980. Eleanor. London: Dent.

SINGER, P. 1985. Prologue: ethics and the new animal liberation. (In Singer, P., ed. In defense of animals. New York: Blackwell. p. 1-10.)

SUKUMAR, R. 2003. The eliving elephants: evolutionary ecology, behaviour, and conservation. Oxford: Oxford University Press.

TAYLOR, P.W. 2002. The ethics of respect for nature. (In Schmidtz, D. \& Willott, E. 2002. Environmental ethics: what really matters, what really works. New York: Oxford University Press. p. 83-95.)

WELADJI, R.B. \& TCHAMBA, M.N. 2003. Conflict between people and protected areas within the Bénoué wildlife conservation area, North Cameroon. Oryx, 37(1):72-79.

WHYTE, I.J. 2001. Conservation management of the Kruger National Park elephant population. Pretoria: UP. (Ph.D. thesis: Zoology.)

WHYTE, I.J. 2002. Headaches and heartaches: the elephant management dilemma. (In Schmidtz, D. \& Willott, E. Environmental ethics: what really matters, what really works. New York: Oxford University Press. p. 293305.)

WHYTE, I.J., BIGGS, H.C., GAYLARD, A. \& BRAACK, L.E.O. 1999. A new policy for the management of the Kruger National Park's elephant population. Koedoe, 42(1):111.

WILLOTT, E. \& SCHMIDTZ, D 2002. Why environmental ethics? (In Schmidtz, D. \& Willott, E. Environmental ethics: what really matters, what really works. New York: Oxford University Press. p. xi-xxi.)

\section{Key concepts:}

conservation

culling

elephants

environmental ethics 


\section{Kernbegrippe:}

bewaring

olifante omgewingsetiek

uitdunning 